Democracy at Work 


\begin{abstract}
A VOLUME IN THE SERIES
Cornell Studies in Political Economy

Edited by Peter J. Katzenstein
\end{abstract}

A full list of titles in the series appears at the end of the book. 


\title{
Democracy at Work
}

\section{CHANGING WORLD MARKETS AND THE FUTURE OF LABOR UNIONS}

\author{
Lowell Turner
}

Cornell University Press 
THIS BOOK HAS BEEN PUBLISHED WITH THE

AID OF A GRANT FROM THE HULL MEMORIAL

PUBLICATION FUND OF CORNELL UNIVERSITY.

Copyright $\mathbb{C}$ I99I by Cornell University

All rights reserved. Except for brief quotations in a review, this book, or parts thereof, must not be reproduced in any form without permission in writing from the publisher. For information address Cornell University Press, I 24 Roberts Place, Ithaca, New York 14850 .

First published I99I by Cornell University Press.

First printing, Cornell Paperbacks, 1992.

International Standard Book Number 0-8014-2627-8 (cloth)

International Standard Book Number o-8o I 4-8 I I 8-X (paper)

Library of Congress Catalog Card Number 9I-55049

Librarians: Library of Congress cataloging information appears on the last page of the book.

(2) The paper in this book meets the minimum requirements of the American National Standard for Information Sciences-

Permanence of Paper for Printed Library Materials, ANSI Z39.48-I984. 
For Kate 
